\title{
Role of wide-angle optical coherence tomography angiography in detection of proliferative diabetic retinopathy in a patient with dense asteroid hyalosis
}

\author{
Akash Belenje, Padmaja Kumari Rani
}

Smt Kanuri Santhamma Centre for Vitreo-Retinal Diseases, LV Prasad Eye Institute, Hyderabad, Telengana, India

\section{Correspondence to} Dr Padmaja Kumari Rani; rpk@lvpei.org

Accepted 9 August 2020

\section{DESCRIPTION}

A 56-year-old woman presented with painless diminution of vision in her left eye since the last 2 months. She is a known case of type 2 diabetes mellitus on insulin. Her best-corrected visual acuity in right eye was 20/60; N8 and left eye were only counting fingers close to face. She was a known case of primary angle-closure glaucoma and had previously undergone peripheral iridotomy in both eyes elsewhere. She had early cataractous lens changes in both eyes. Her left eye, in addition, also showed faint iris neovascularisation at 2'o clock. Her intraocular pressure in the right and left eye was 16 and $20 \mathrm{~mm} \mathrm{Hg}$, respectively. She was not on any antiglaucoma medications at the time of presentation. Her right eye fundus (figure 1A) showed dense asteroid hyalosis $(\mathrm{AH})$ with optic disc showing 0.5 cup disc ratio and dot and blot haemorrhages in the retina. With the presence of proliferative diabetic retinopathy, changes including neovascularisation were obscured due to dense $\mathrm{AH}$ in the right eye. Left eye fundus (figure 1B) showed dense $\mathrm{AH}$ with vitreous haemorrhage $(\mathrm{VH})$ and the optic disc was hazily seen. She was imaged using wide-angle swept source optical coherence tomography angiography (OCTA) $12 \mathrm{~mm}$ field of view (PLEX Elite 9000; Carl Zeiss Meditec, Dublin, California, USA). This showed capillary non-perfusion areas and neovascularisation fronds in the right eye (figure 2A), while left eye OCTA revealed only capillary nonperfusion areas. Posterior pole view of left eye was obscured due to artefacts caused by VH (figure 2B). Panretinal photocoagulation was performed adequately in the peripheral visible retina where the $\mathrm{AH}$ was not as dense as near the posterior pole in both eyes based on the diagnosis of proliferative diabetic retinopathy (PDR).

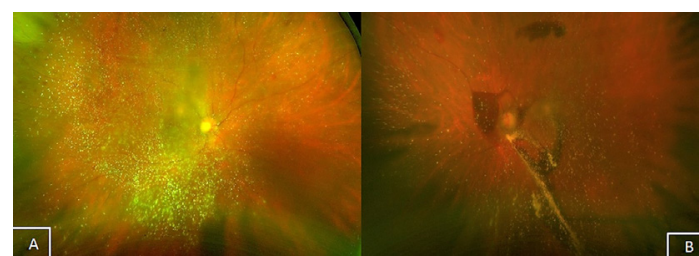

Figure 1 (A) Composite fundus image of right eye with dense $\mathrm{AH}$ obscuring the proliferative neovascularisation changes in the retina. (B) Composite fundus image of left eye showing dense $\mathrm{AH}$ with $\mathrm{VH}$ due to proliferative diabetic retinopathy. $\mathrm{AH}$, asteroid hyalosis; $\mathrm{VH}$, vitreous haemorrhage.

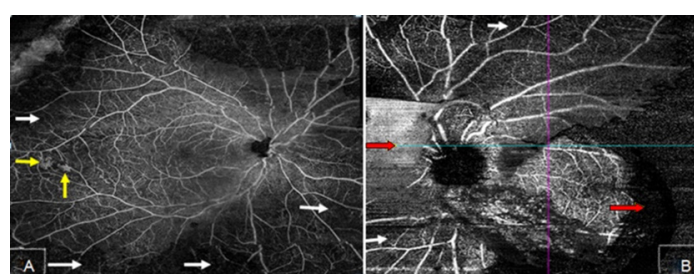

Figure 2 (A) Composite wide-angle OCTA of right eye showing extensive capillary non-perfusion areas (white arrows) and neovascularisation elsewhere (yellow arrows). (B) Composite wide-angle OCTA of left eye showing capillary non perfusion areas (white arrows) and artefacts in area corresponding to vitreous haemorrhage (red arrows). OCTA, optical coherence tomography angiography.

Fundus fluorescein angiography (FFA) is the gold standard in detecting diabetic retinopathic changes in cases of dense AH. The barrier filters in the FFA camera allow only green light and absorb all scattered blue light, helping with retinal visualisation. ${ }^{1}$ But FFA is time consuming, invasive and can also, although rarely, life-threatening dye-related complications. With advent of OCTA, a non-invasive dye less imaging of retinal and choroidal vasculature is possible. ${ }^{2}$ OCTA's effectiveness in the detection of retinal and choroidal abnormalities in the presence of $\mathrm{AH}$ has been reported. ${ }^{3}$ Our case shows the usefulness of wide-angle OCTA in the detection of neovascularisation and capillary drop out areas even in the presence of dense AH. Vitreous opacities such as thick $\mathrm{VH}$ and posterior vitreous detachment can cause multiple black shadow, such as areas of artefacts in all slabs, similar to capillary non-perfusion in OCTA. ${ }^{4}$ In our case, the left eye showed similar artefacts due to the presence of VH. Wide-angle OCTA can be a promising tool for

\section{Learning points}

- Wide-angle optical coherence tomography angiography (OCTA) allows for the dye less visualisation of retinal vasculature avoiding invasive imaging modality, such as the fundus fluoresceinangiography.

- Wide-angle OCTA can be a promising tool for the detection of neovascularisation and capillary non perfusion areas of proliferativediabetic retinopathy in the presence of dense asteroid hyalosis. 
the detection of neovascularisation and capillary non-perfusion areas in eyes with dense $\mathrm{AH}$.

Contributors $A B$ collected data, literature search and wrote the manuscript. PKR conceived the concept, managed the case and involved in reviewing and editing of manuscript.

Funding Hyderabad Eye Research Foundation.

Competing interests None declared.

Patient consent for publication Parental/guardian consent obtained.

Provenance and peer review Not commissioned; externally peer reviewed.
ORCID iD

Padmaja Kumari Rani http://orcid.org/0000-0001-7069-8238

\section{REFERENCES}

1 Hampton GR, Nelsen PT, Hay PB. Viewing through the asteroids. Ophthalmology 1981;88:669-72.

2 de Carlo TE, Bonini Filho MA, Baumal CR, et al. Evaluation of preretinal neovascularization in proliferative diabetic retinopathy using optical coherence tomography angiography. Ophthalmic Surg Lasers Imaging Retina 2016;47:115-9.

3 Rani PK, Prajapati RC. Role of OCT angiography in the detection of retinal vascular and macular abnormalities in subjects with asteroid Hyalosis. Semin Ophthalmol 2018:1-5.

4 Konana VK, Shanmugam PM, Ramanjulu R, et al. Vitreous opacities causing artifacts in optical coherence tomography angiography. Indian J Ophthalmol 2017;65:1023-4.

Copyright 2020 BMJ Publishing Group. All rights reserved. For permission to reuse any of this content visit

https://www.bmj.com/company/products-services/rights-and-licensing/permissions/

BMJ Case Report Fellows may re-use this article for personal use and teaching without any further permission.

Become a Fellow of BMJ Case Reports today and you can:

- Submit as many cases as you like

- Enjoy fast sympathetic peer review and rapid publication of accepted articles

Access all the published articles

Re-use any of the published material for personal use and teaching without further permission

\section{Customer Service}

If you have any further queries about your subscription, please contact our customer services team on +44 (0) 2071111105 or via email at support@bmj.com.

Visit casereports.bmj.com for more articles like this and to become a Fellow 